\title{
The Influence of Silver Nanoparticles on the Blood-Brain and the Blood- Cerebrospinal Fluid Barrier in vitro
}

Sandra Cramer ${ }^{1}$, Sebastian Tacke ${ }^{2}$, Julia Bornhorst ${ }^{3}$, Amit K Sachan $^{1}$, Jürgen Klingauf ${ }^{2}$, Tanja Schwerdtle ${ }^{3}$ and Hans-Joachim Galla ${ }^{1 *}$

${ }^{1}$ Institute of Biochemistry, University of Münster, Wilhelm-Klemm-Straße 2, D-48149 Münster, Germany

${ }^{2}$ Institute of Medical Physics and Biophysics, University of Münster, Robert-Koch-Str. 31, D-48149 Münster, Germany

${ }^{3}$ Institute of Nutritional Sciences, University of Potsdam, Arthur-Scheunert-Allee 114-116, 14558 Nuthetal, Germany

\begin{abstract}
The use of silver nanoparticles in medical and consumer products such as wound dressings, clothing and cosmetic has increased significantly in recent years. Still, the influence of these particles on our health and especially on our brain, has not been examined adequately up to now. We studied the influence of AgEO- (Ethylene Oxide) and AgCitrate-Nanoparticles (NPs) on the protective barriers of the brain, namely the blood-brain barrier (BBB) and the blood-cerebrospinal fluid (blood-CSF) barrier in vitro. The NPs toxicity was evaluated by examining changes in membrane integrity, cell morphology, barrier properties, oxidative stress and inflammatory reactions. AgNPs decreased cell viability, disturbed barrier integrity and tight junctions and triggered oxidative stress and DNA strand breaks. However, all mentioned effects were, at least partly, suppressed by a Citrate-coating and were most pronounced in the cells of the BBB as compared to the epithelial cells representing the blood-CSF barrier. AgEO- but not AgCitrate-NPs also triggered an inflammatory reaction in porcine brain capillary endothelial cells (PBCEC), which represent the BBB. Our data indicate that AgNPs may cause adverse effects within the barriers of the brain, but their toxicity can be reduced by choosing an appropriate coating material.
\end{abstract}

Keywords: Blood-brain barrier; Blood-cerobrospinal fluid barrier; Silver nanoparticles; Transcellular resistance; Inflammation; Oxidative stress; DNA damage; Cytotoxicity

Abbreviations: BBB: Blood-Brain Barrier; BSE: Back Scattered Electrons; CSF: Cerebrospinal Fluid; COX-2: Cyclooxygenase-2; CP: Choroid Plexus; EO: Ethylene Oxide; MMP-2: Matrix Metalloproteinase-2; NP: Nanoparticle; PBCEC: Porcine Brain Capillary Endothelial Cells; PCPEC: Porcine Choroid Plexus Epithelial Cells; RONS: Reactive Oxygen and Nitrogen Species; SEM: Scanning Electron Microscopy; TEM: Transmission Electron Microscopy; TER: Transcellular Electrical Resistance

\section{Introduction}

Silver nanoparticles (Ag-NPs) have gained an increasing attention due to their antimicrobial and antiviral activities and are used in a large number of consumer products including electronics, paint, clothing, food and medical devices [1]. According to the WoodrowWilson database, about $24 \%$ of all consumer products that consist of engineered NPs contain nanosilver ([2] www.nanotechproject.org). But besides their widespread use and favorable characteristics, there have been some concerns about their safety. Various studies have reported adverse health effects including induction of inflammation, cytotoxicity, oxidative stress and genotoxic effects in a great variety of cell types [36]. The main routes of exposure for Ag-NPs are inhalation, skin contact and ingestion. In in vivo studies conducted in rats, it has been shown that Ag-NPs accumulate in various organs including the brain after both oral exposure [7] and inhalation [8]. Additionally, it has also been shown that Ag-NPs are able to translocate through and accumulate in primary rat brain microvascular endothelial cells [9]. Thereby, it is important to also study the effects of Ag-NPs on the barriers of the central nervous system, namely the blood-brain barrier (BBB) and the bloodcerebrospinal fluid (CSF) barrier. The BBB separates the blood from the brain interstitial fluid and consists mainly of capillary endothelial cells that line cerebral microvessels and that are closely connected by tight junctions which prevent uncontrolled paracellular flux [10]. The second barrier system within the CNS, the blood-CSF barrier, is build by the epithelial cells of the choroid plexus (CP). Similarly to the BBB, this epithelial barrier system separates the blood from the CSF and is also sealed by tight junctions between adjacent cells which are located at the CSF-facing surface. The tight junctions are indispensable since the endothelium of the CP is leaky and permeable. Besides CSF secretion, the $\mathrm{CP}$ is involved in maintaining brain homeostasis and in the defense against harmful substances [11]. An infiltration of the brain with xenobiotics, such as NP, may lead to an inflammation of brain tissue and/or oxidative stress responses. Inflammation of the brain is mediated by a concerted secretion of cytokines (Interleukin-1 $\beta$ [IL-1 $1 \beta$ ], tumor necrosis factor alpha [TNF- $\alpha$ ], ect) and other inflammatory mediators such as adhesion molecules (VCAM-1, ICAM-1) and enzymes (nitric oxide synthase [iNOS], matrix metalloproteinases [MMPs]). All of these are involved in the subsequent invasion of peripheral leukocytes into the brain and play a role in resulting brain damage [12].

To date, there are only few studies that have elucidated the various effects of Ag-NPs on the BBB. Tricker et al. [13] have examined the effect of differently sized Ag-NPs on primary rat brain endothelial cells [13]. They found a size-dependent pro-inflammatory response through the release of prostaglandin $E_{2}$, TNF- $\alpha$ and Il- $1 \beta$ and an increase in BBB permeability after exposure to Ag-NPs. Another study elucidated the cytotoxic effect of Ag-NPs on a rat brain endothelial cell line [14]. They also found a size- and concentration-dependent cytotoxic effect of AgNPs, the smallest particle being the most harmful.

*Corresponding author: Hans-Joachim Galla, Institute of Biochemistry University of Münster, Wilhelm-Klemm-Straße 2, D-48149 Münster Germany, Tel: 49-251-8333205; E-mail: gallah@uni-muenster.de

Received July 25, 2014; Accepted August 23, 2014; Published August 27, 2014 Citation: Cramer S, Tacke S, Bornhorst J, Klingauf J, Schwerdtle T, et al (2014) The Influence of Silver Nanoparticles on the Blood-Brain and the BloodCerebrospinal Fluid Barrier in vitro. J Nanomed Nanotechnol 5: 225. doi: 10.4172/2157-7439.1000225

Copyright: (C) 2014 Cramer S, et al. This is an open-access article distributed under the terms of the Creative Commons Attribution License, which permits unrestricted use, distribution, and reproduction in any medium, provided the original author and source are credited. 
Citation: Cramer S, Tacke S, Bornhorst J, Klingauf J, Schwerdtle T, et al. (2014) The Influence of Silver Nanoparticles on the Blood-Brain and the Blood-Cerebrospinal Fluid Barrier in vitro. J Nanomed Nanotechnol 5: 225. doi: 10.4172/2157-7439.1000225

Page 2 of 12

The aim of the present in vitro study was to analyze the effects of two differently modified Ag-NPs (Ethylene oxide [EO] and Citrate) on primary porcine brain capillary endothelial cells (PBCEC) and, for the first time, on primary capillary choroid plexus epithelial cells (PCPEC). We analyzed the impact on the integrity and permeability of the BBB and the blood-CSF barrier and on tight junction expression and localization. We also evaluated the cellular responses after addition of Ag-NPs including cytotoxicity, oxidative stress, inflammation and genotoxicity.

\section{Results}

\section{Cytotoxicity testing}

First, we investigated the cytotoxicity of AgEO- and AgCitrateNPs using the neutral red uptake assay and a microscopic evaluation of cell morphology. Figure 1 shows the results of the neutral red uptake assay measuring the lysosomal integrity after exposure of primary brain capillary endothelial cells (PBCEC, Figure 1A)) and primary choroid plexus epithelial cells (PCPEC, Figure 1B) to varying concentrations of AgEO- and AgCitrate-NPs. In both barrier models, AgEO-NPs exhibited a higher cytotoxicity than AgCitrate-NPs and PBCEC were more sensitive as compared to PCPEC. In PBCEC, a significant decrease of cell viability was found starting at $50 \mu \mathrm{g} /$ $\mathrm{mL}$ for both AgEO- $((58 \pm 4) \%)$ and AgCitrate-NPs $((71 \pm 6) \%)$. In PCPEC, a concentration-dependent reduction of neutral red uptake was detected starting from $100 \mu \mathrm{g} / \mathrm{mL}((77 \pm 7) \%)$ for AgEONPs while AgCitrate-NPs did not induce a significant effect in the concentrations tested. Additionally, changes in cell morphology were examined microscopically $24 \mathrm{~h}$ after treatment of PBCEC and PCPEC with AgEO- and AgCitrate-NP (Figure 1C-E). The untreated PBCEC possess the typical spindle-like cell morphology and a high degree of organization (Figure 1C). After a treatment with AgEO-NPs $(50 \mu \mathrm{g} /$
$\mathrm{mL})$ some minor gaps start appearing within the cell monolayer and cell debris becomes visible (Figure 1D). In case of AgCitrate-NPs minor gaps within the cell monolayer appear only at a concentration of $75 \mu \mathrm{g} /$ $\mathrm{mL}$ (Figure 1E). Thereby, in the subsequent experiments, only Ag-NP concentrations up to $25 \mu \mathrm{g} / \mathrm{mL}$ were employed. The untreated PCPEC exhibit a cobblestone-like morphology which is typical for epithelial cells. This remains unchanged after treatment with both AgEO- and AgCitrate-NP in concentrations up to $75 \mu \mathrm{g} / \mathrm{mL}$ (data not shown).

\section{Uptake of Ag-NPs}

In order to locate the Ag-NPs within the cellular context of the PCPEC and PBCEC, both, scanning and transmission electron microscopic investigations were performed. First, it was clarified whether the Ag-NPs agglomerate on the membrane and/or enter the cells by using scanning electron microscopy (SEM). This technique offers the opportunity to examine surface features as well as to gain information buried inside the specimen: secondary electrons reveal the surface information whereas backscattered electrons (BSE) carry information from structures within the sample, due to their higher excitation depth. Additionally, the back scattering contrast is strongly dependent on the atomic number, which allows the identification of regions with high and low mean atomic number, for example silver and carbon, respectively. For all electron microscopic investigations, cells were treated with $25 \mu \mathrm{g} / \mathrm{mL}$ of AgEO- and AgCitrate-NP for $6 \mathrm{~h}$ and $24 \mathrm{~h}$. As there was no difference recognizable in the SEM experiments between the samples incubated for $6 \mathrm{~h}$ and $24 \mathrm{~h}$ or between the types of NPs used, only the results after $6 \mathrm{~h}$ of incubation with AgEO-NPs are shown. Figure 2A shows a typical SE image of an untreated monolayer of PBCEC. The tight cell network is clearly visible but internal features of the cell remain concealed. In contrast to the SE image, the cell nucleus, vesicles and cell organelles like the golgi apparatus can be identified in the BSE image (Figure 2B). Especially vesicles appear as bright spots
A

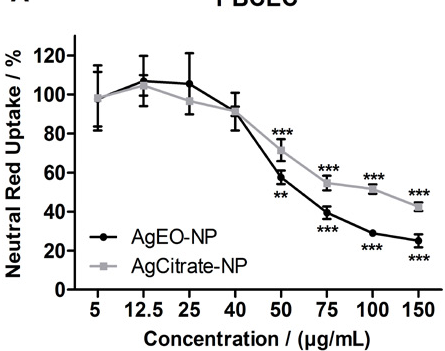

B

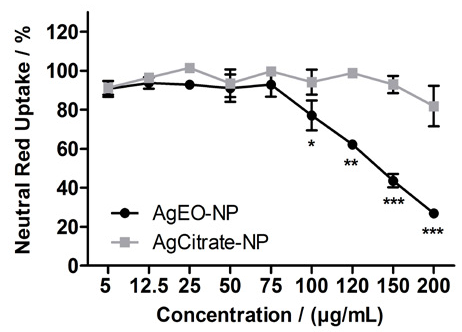

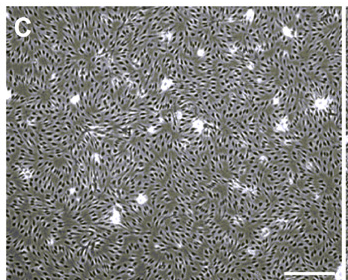
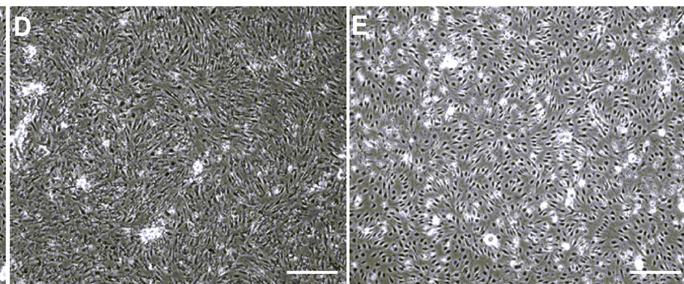

Figure 1: The influence of AgNPs on cell viability of PBCEC and PCPEC.

A) Neutral Red Uptake Assay of PBCEC incubated with Ag-NPs (24 h). The values indicate relative neutral red uptake compared to the untreated control. The data are expressed as means \pm SEM, $n>3$.

B) Neutral Red Uptake Assay of PCPEC incubated with Ag-NPs $(24 \mathrm{~h})$. The values indicate relative neutral red uptake compared to the untreated control. The data are expressed as means \pm SEM, $n=3$.

C)-E) PBCEC monolayer after treatment with AgEO- and AgCitrate-NPs for $24 \mathrm{~h}$. Scale Bar: $100 \mu \mathrm{m}$

C) untreated control D) AgEO-NP $50 \mu \mathrm{g} / \mathrm{mL}$ E) AgCitrate-NP $75 \mu \mathrm{g} / \mathrm{mL}$ 
Citation: Cramer S, Tacke S, Bornhorst J, Klingauf J, Schwerdtle T, et al. (2014) The Influence of Silver Nanoparticles on the Blood-Brain and the Blood-Cerebrospinal Fluid Barrier in vitro. J Nanomed Nanotechnol 5: 225. doi: 10.4172/2157-7439.1000225

Page 3 of 12
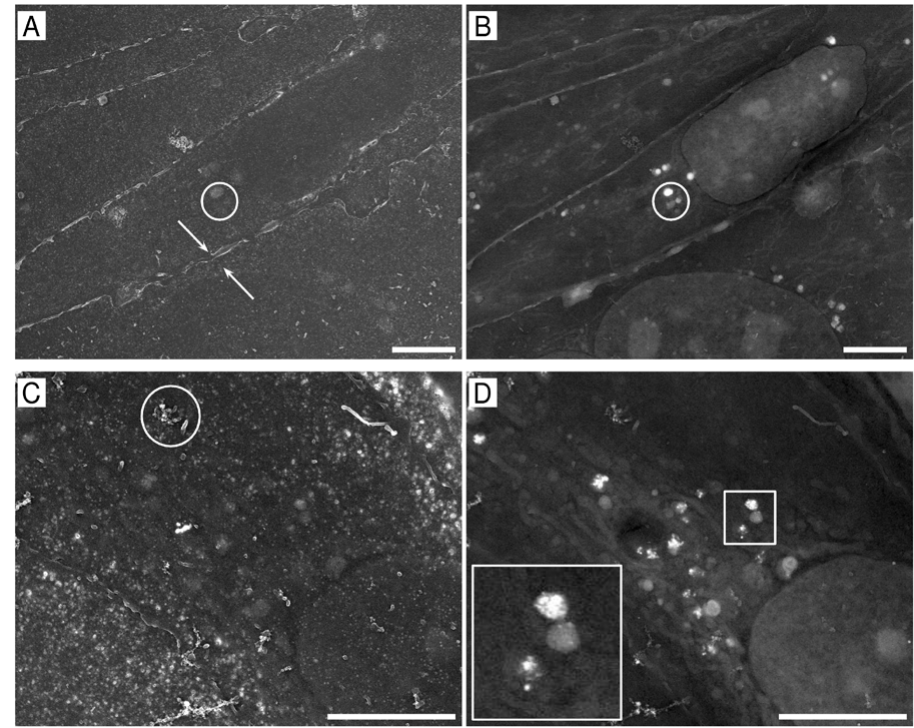

Figure 2: SE and BSE images of PBCEC

A) Secondary electron image of the PBCEC. The arrows mark the border of two cells. The cell network can clearly be identified. Scale bar: $5 \mu$ m. B) Backscattered electron image of the same region as in A). The circle in A) and B) highlights vesicles which appear as bright spots in the BSE image due to the high density of membranes which are stained by osmium tetroxide. In the SE image the vesicles are hardly visible since the SE signal is surface sensitive. In contrast to a), the internal structures of the cell can be visualized by the BSE signal. Scale bar: $5 \mu \mathrm{m}$. C) SE image of PBCEC incubated with AgEO-NPs for $6 \mathrm{~h}$. The circle frames an area were membrane bound nanoparticles are visible. Such events are found frequently all over the specimen. Scale bar: $4 \mu \mathrm{m}$. D) BSE image of the same region as in C). The inset shows a close up of an empty vesicle and two vesicles filled with nanoparticles. Scale bar: $4 \mu \mathrm{m}$. In all images the contrast and brightness was rescaled in order to improve the visualization of the cell organelles.

due to the high density of membranes stained by osmium tetroxide. However, differences to the control experiment can clearly be spotted in the cells incubated with Ag-NPs. In the SE images, membrane bound NPs can be located (circled area in Figure 2C). Additionally, as shown in Figure 2D, Ag-NPs can also be identified in the BSE image. Besides the agglomeration on the outer membrane, the BSE images clearly reveal that the NPs enter the cell, and additionally, the images suggest an endocytotic pathway for the access of the NPs (Figure 2D inset). In order to correlate cellular ultrastructure and NPs uptake, transmission electron microscopy (TEM) was performed for PBCEC and PCPEC. As indicated by the SEM experiments, both AgEO- and AgCitrate, interact strongly with the PBCEC membrane and enter the cytoplasm by endocytosis (Figure 3B). Within the cytoplasm AgEOas well as AgCitrate NPs accumulate into nano-aggregates (Figure 3B-D). Single particles can still be resolved within these clumps. Besides these agglomerates, nanoparticles could not be found in the mitochondria or nucleus. Compared to the PBCEC sample, Ag-NPmembrane interaction and accumulation within the cytoplasma are dramatically decreased in PCPEC. Infrequently, nano-clusters or single nanoparticles can be found within the cell but in general, experiments with cells exposed to the NPs resemble the control situation (data not shown).

\section{Assessment of barrier function and cell permeability}

As the integrity of the BBB and the blood-CSF barrier is important for the protection of the brain, we investigated the influence of AgNPs on the barrier integrity of PBCEC and PCPEC. In a first step, transcellular electrical resistance (TER) measurements were employed (Figure 4). In PBCEC both AgEO- and AgCitrate-NPs induced a concentration-dependent decrease of the TER (Figure 4A). An incubation of PBCEC with $25 \mu \mathrm{g} / \mathrm{mL}$ of AgEO-NPs reduced the TER to $(11 \pm 5) \%$ after $24 \mathrm{~h}$, while $25 \mu \mathrm{g} / \mathrm{mL}$ AgCitrate-NPs decreased the
TER only to $(33 \pm 7) \%$ of the undisturbed cell monolayer. In PCPEC the Ag-NPs did not induce any changes in TER (Figure 4C). The results of the TER measurements were then confirmed by evaluation of the FITC-Dextrane transport across the PBCEC and PCPEC monolayer under the influence of the Ag-NPs (Figure 4B and D). After addition of AgEO-NPs $(25 \mu \mathrm{g} / \mathrm{mL})$ to PBCEC, the permeability rate reached a value of $\left(2.5 \cdot 10^{-7} \pm 4.0 \cdot 10^{-8}\right) \mathrm{cm} / \mathrm{s}$ while the untreated control exhibited a value of $\left(6.1 \cdot 10^{-8} \pm 4.0 \cdot 10^{-9}\right) \mathrm{cm} / \mathrm{s}$ after $24 \mathrm{~h}$. The exposure of PBCEC to AgCitrate-NPs $(25 \mu \mathrm{g} / \mathrm{mL})$ increased the permeability rate to $\left(1.3 \cdot 10^{-7} \pm 3.2 \cdot 10^{-9}\right) \mathrm{cm} / \mathrm{s}$. In PCPEC, no change in cell permeability was observed (Figure 4D). Thereby, the results of the permeability measurement support the TER measurements.

\section{Integrity of the tight junctions}

An impairment of barrier function is often caused by changes in tight junction expression and localization. Thereby, the expression and localization of the tight junction protein occludin was examined by both, Western Blot analysis and immunochemistry. The results of the Western Blot analysis indicated that the observed disruption of barrier integrity in PBCEC was not due to a changed expression of occludin (data not shown). However, the results of the immunostaining (Figure 5) revealed that the observed barrier break-down may rather be caused by a change in tight junction organization and integrity. The untreated PBCEC exhibit the characteristic spindle-like cell morphology, a high degree of organization and straight and continuous cells borders (Figure 5A). After treatment with AgEO-NPs $(25 \mu \mathrm{g} / \mathrm{mL})$, the PBCEC become slightly bigger and the cell borders appear more fuzzy and patchy (Figure 5B). This effect can also be observed, to a lesser extent, after addition of AgCitrate-NP $(25 \mu \mathrm{g} / \mathrm{mL})$ (Figure $5 \mathrm{C})$. In PCPEC however, no changes in occludin localization and formation are induced upon addition of Ag-NPs, which is in agreement with the TER and permeability measurements (Figure 5D-F). 
Citation: Cramer S, Tacke S, Bornhorst J, Klingauf J, Schwerdtle T, et al. (2014) The Influence of Silver Nanoparticles on the Blood-Brain and the Blood-Cerebrospinal Fluid Barrier in vitro. J Nanomed Nanotechnol 5: 225. doi: 10.4172/2157-7439.1000225
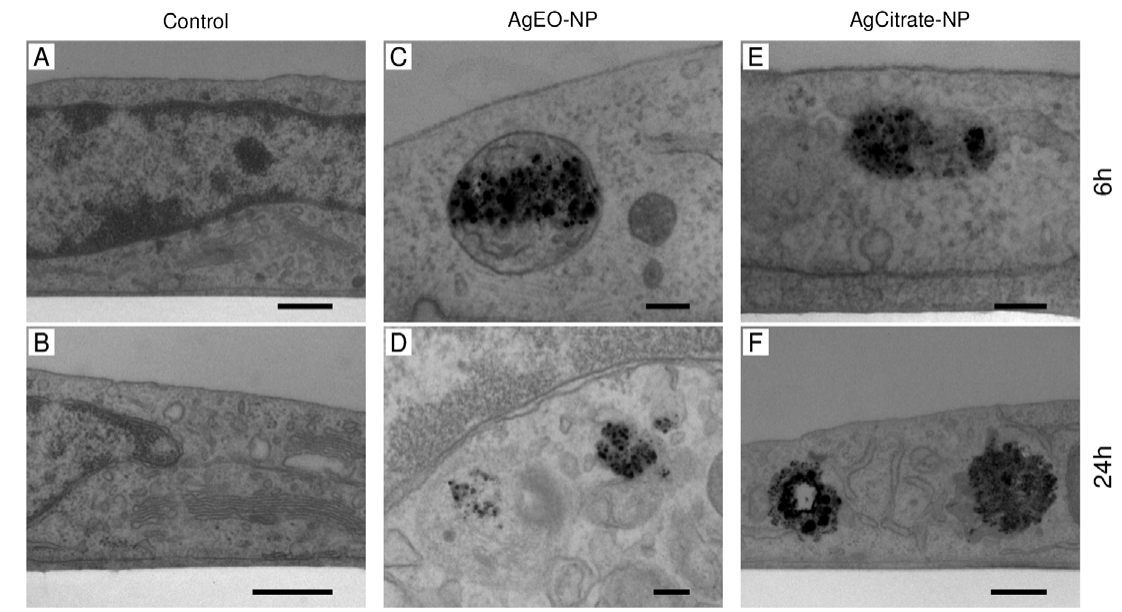

Figure 3: Bright field TEM images of PBCEC

A) \& B) The images show well preserved cells. Cell organelles, cell nucleus and membranes are clearly visible. Scale bars $500 \mathrm{~nm}$. C) Here, a vesicle filled with NPs is shown. Scale bar $100 \mathrm{~nm}$ D), E) and F) Accumulations of NPs in the cytoplasm. Scale bars: D) $100 \mathrm{~nm}$, E) $100 \mathrm{~nm}$ and F) $500 \mathrm{~nm}$. In all images the contrast and brightness was rescaled in order to improve the visualization of the cell organelles.

A

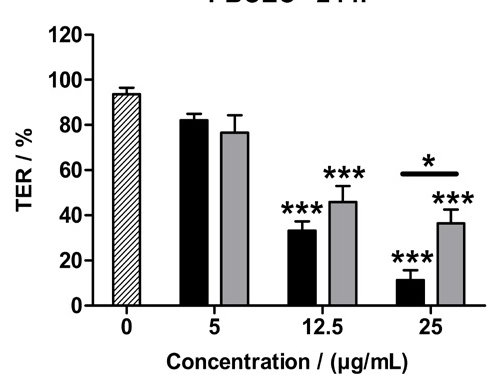

AgEO-NP

$\square$ AgCitrat-NP

C

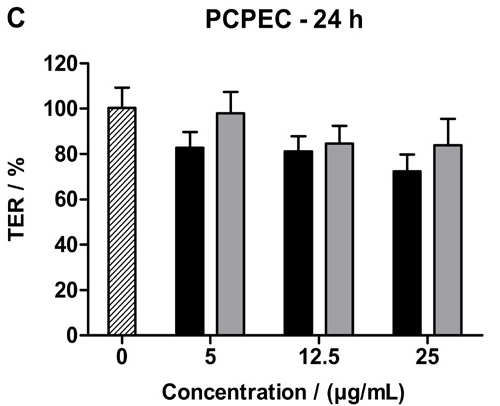

AgEO-NP

$\square$ AgCitrate-NP
B

PBCEC

FITC-Dextrane Permeability

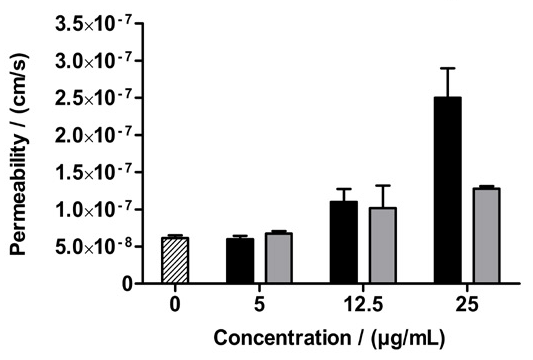

AgEO-NP

$\square$ AgCitrate-NP

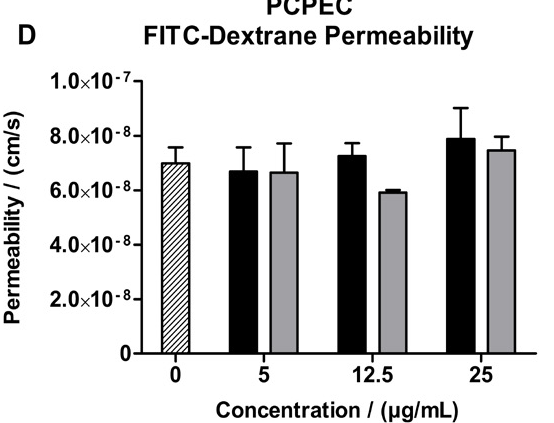

AgEO-NP

AgCitrate-NP

Figure 4: The influence of Ag-NPs on the barrier integrity of PBCEC and PCPEC.

A) TER values after treatment of triplicate PBCEC monolayers with AgEO- and AgCitrate-NPs for $24 \mathrm{~h}$. The values are relative to their respective starting value prior to NP addition. The data are expressed as means \pm SEM, $n \geq 5$. The absolute TER values ranged between 600 and $1000 \Omega \cdot \mathrm{cm}^{2}$.

B) FITC-Dextrane permeability after treatment of triplicate PBCEC monolayers with AgEO- and AgCitrate-NPs for $24 \mathrm{~h}$. The data are expressed as means \pm SD of a single measurement. $n=3$. The absolute TER values ranged between 600 and $1000 \Omega \cdot \mathrm{cm}^{2}$.

C) TER values after treatment of triplicate PCPEC monolayers with AgEO- and AgCitrate-NPs for 24 h. The values are relative to their respective starting value prior to NP addition. The data are expressed as means \pm SEM, $n=3$. The absolute TER values ranged between 600 and $1000 \Omega \cdot \mathrm{cm}^{2}$.

D) FITC-Dextrane permeability after treatment of triplicate PCPEC monolayers with AgEO- and AgCitrate-NPs for $24 \mathrm{~h}$. The data are expressed as means \pm SD of a single measurement. $n=3$. The absolute TER values ranged between 600 and $1000 \Omega \cdot \mathrm{cm}^{2}$. 
Citation: Cramer S, Tacke S, Bornhorst J, Klingauf J, Schwerdtle T, et al. (2014) The Influence of Silver Nanoparticles on the Blood-Brain and the Blood-Cerebrospinal Fluid Barrier in vitro. J Nanomed Nanotechnol 5: 225. doi: 10.4172/2157-7439.1000225

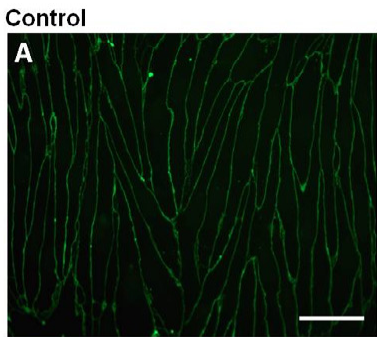

AgEO-NP $25 \mu \mathrm{g} / \mathrm{mL}$
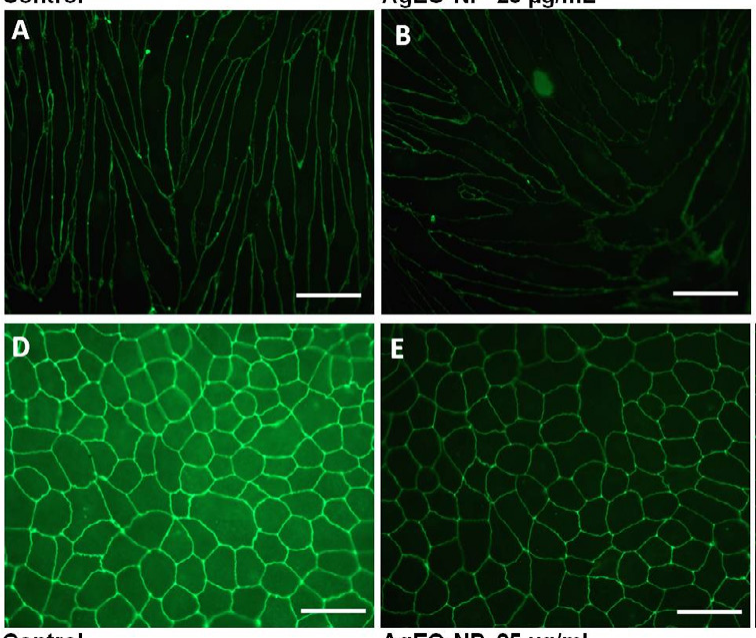

Control

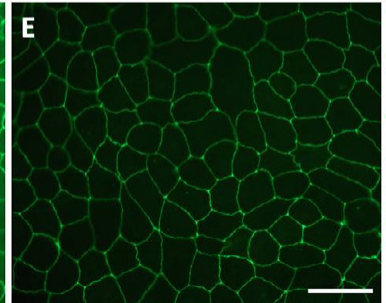

AgEO-NP $25 \mu \mathrm{g} / \mathrm{mL}$
AgCitrate-NP $25 \mu \mathrm{g} / \mathrm{mL}$
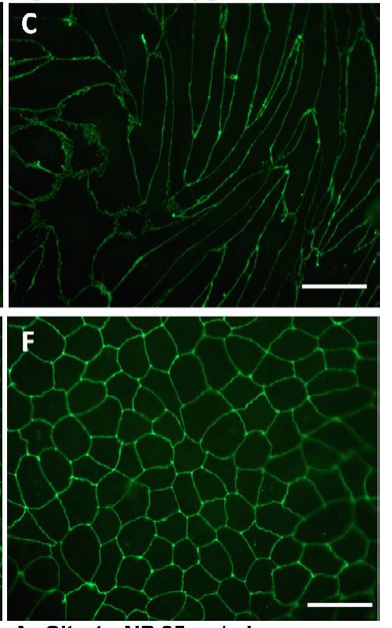

AgCitrate-NP $25 \mu \mathrm{g} / \mathrm{mL}$

Figure 5: Immunostaining analysis of occludin after treatment of PBCEC and PCPEC monolayers with AgEO- and AgCitrate-NPs for $24 \mathrm{~h}$.

A) PBCEC: untreated control B) PBCEC: AgEO-NP $25 \mu \mathrm{g} / \mathrm{mL}$ C) PBCEC: AgCitrate-NP $25 \mu \mathrm{g} / \mathrm{mL}$ D) PCPEC: untreated control E) PCPEC: AgEO-NP 25 gg/mL F) PCPEC: AgCitrate-NP $25 \mu \mathrm{g} / \mathrm{mL}$.
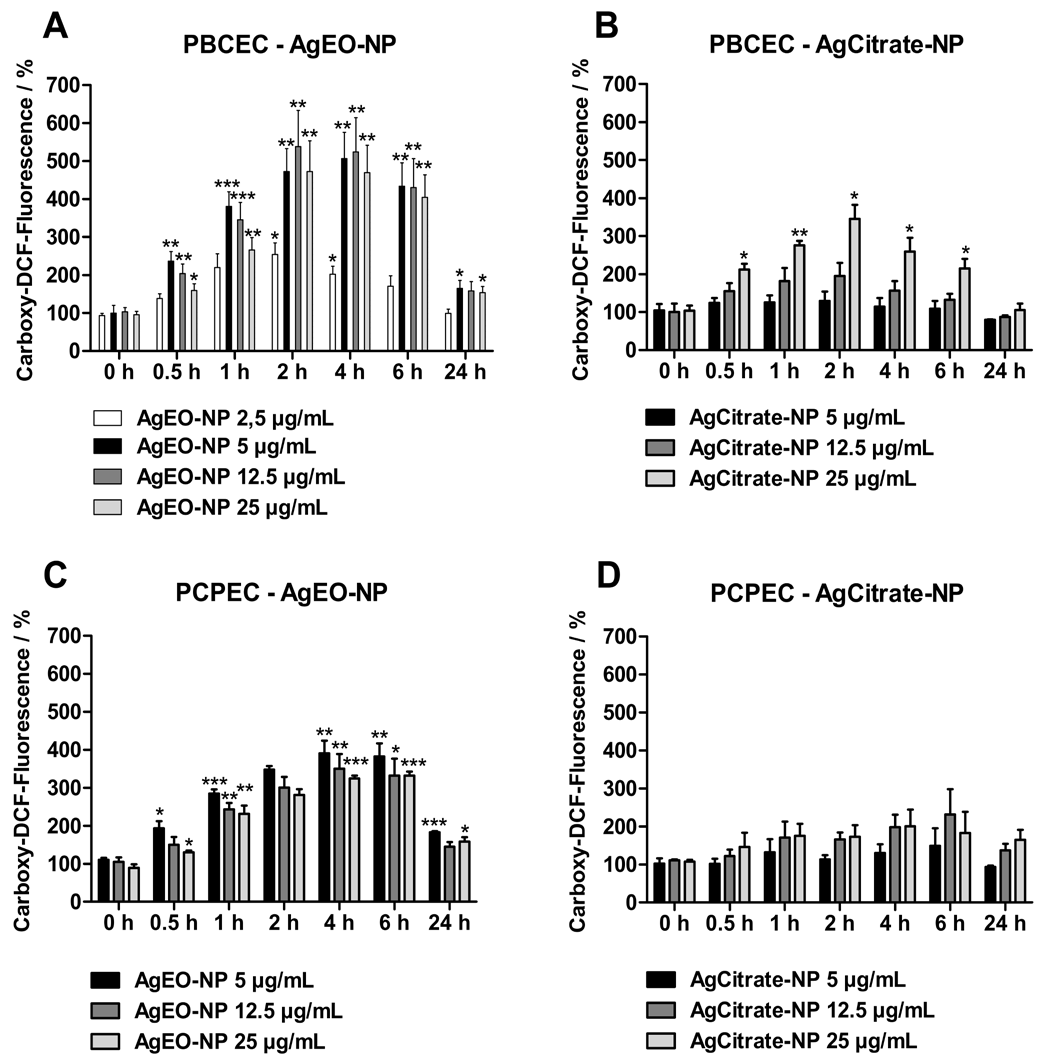

Figure 6: Induction of RONS after treatment of PBCEC and PCPEC with AgEO- and AgCitrate-NPs for $24 \mathrm{~h}$.

A) Time-dependent Carboxy-DCF-Fluorescence after treatment of PBCEC with AgEO-NPs $(n \geq 3)$.

B) Time-dependent Carboxy-DCF-Fluorescence after treatment of PBCEC with AgCitrate-NPs $(n \geq 3)$.

C) Time-dependent Carboxy-DCF-Fluorescence after treatment of PCPEC with AgEO-NPs $(n=3)$

D) Time-dependent Carboxy-DCF-Fluorescence after treatment of PCPEC with AgCitrate-NPs $(n=3)$.

The values are relative to the untreated control at every time-point. The data are expressed as means \pm SEM. The absolute fluorescence values of the control were $91 \pm 12$ fluorescence units after 0 h, $536 \pm 58$ fluorescence units after $2 \mathrm{~h}, 1627 \pm 111$ fluorescence units after $4 \mathrm{~h}, 3082 \pm 78$ fluorescence units after $6 \mathrm{~h}$ and $10885 \pm 276$ fluorescence units after $24 \mathrm{~h}$. 
Citation: Cramer S, Tacke S, Bornhorst J, Klingauf J, Schwerdtle T, et al. (2014) The Influence of Silver Nanoparticles on the Blood-Brain and the Blood-Cerebrospinal Fluid Barrier in vitro. J Nanomed Nanotechnol 5: 225. doi: 10.4172/2157-7439.1000225

Page 6 of 12

\section{Oxidative stress and DNA damage}

As the generation of oxidative stress constitutes a major factor in nanoparticle toxicity, the potential of AgEO- and AgCitrate-NPs to generate reactive oxygen and nitrogen species (RONS) has been evaluated in PBCEC and PCPEC after different time-points $(0 \mathrm{~h}, 1 \mathrm{~h}$, $2 \mathrm{~h}, 4 \mathrm{~h}, 6 \mathrm{~h}$ and $24 \mathrm{~h}$ ). In PBCEC (Figure $6 \mathrm{~A}$ and B), a concentration and time-dependent generation of RONS has been detected, the maximum being reached between $2 \mathrm{~h}$ and $6 \mathrm{~h}$. After addition of AgEONPs (Figure 6A) a significant increase of RONS was found starting at a concentration of $2.5 \mu \mathrm{g} / \mathrm{mL}(2 \mathrm{~h}: 250 \pm 30 \%)$, the highest increase was detected in a concentration range between $5 \mu \mathrm{g} / \mathrm{mL}$ and $25 \mu \mathrm{g} / \mathrm{mL}(25$ $\mu \mathrm{g} / \mathrm{mL}, 2 \mathrm{~h}: 470 \pm 80 \%)$. After $24 \mathrm{~h}$ of incubation the relative RONS levels started to decrease again, which was due to a rise of RONS in the untreated control. Thereby, the relative RONS values after $24 \mathrm{~h}$ have to be interpreted carefully. Under the influence of AgCitrate-NPs (Figure 6B) a significant but smaller increase of RONS has been detected as well, reaching the maximum between $2 \mathrm{~h}$ and $4 \mathrm{~h}(25 \mu \mathrm{g} / \mathrm{mL}, 2 \mathrm{~h}: 350 \pm$ $40 \%)$.

In PCPEC (Figure 6C and D), a significant increase in RONS levels was detected after $1 \mathrm{~h}$ of AgEO-NP exposure, reaching its peak at $4 \mathrm{~h}$ $(25 \mu \mathrm{g} / \mathrm{mL}: 325 \pm 7 \%)$ and $6 \mathrm{~h}(25 \mu \mathrm{g} / \mathrm{mL}: 330 \pm 10 \%)$. Again, RONS level started to decrease afterwards but were still significantly elevated after $24 \mathrm{~h}(160 \% \pm 12 \%)$. AgCitrate-NPs (Figure 6D), on the other hand, led to a slight but not significant increase of RONS between $1 \mathrm{~h}$ and $6 \mathrm{~h}(4 \mathrm{~h}, 25 \mu \mathrm{g} / \mathrm{mL}: 200 \% \pm 44 \%)$.

As a rise in RONS may induce damage at the DNA level, the DNA strand breaks per cell upon exposure $(24 \mathrm{~h})$ of PBCEC and PCPEC to Ag-NPs were evaluated (Figure 7). AgEO-NPs induced a significant and concentration dependent amount of DNA strand breaks per cell after $24 \mathrm{~h}(25 \mu \mathrm{g} / \mathrm{mL}(8060 \pm 2320)$ strand breaks per cell, AgEO $12.5 \mu \mathrm{g} /$ $\mathrm{mL}(3020 \pm 270)$ strand breaks per cell $)$ while AgCitrate-NPs did not. In PCPEC, Ag-NPs did not stimulate strand breaks at a concentration of $12.5 \mu \mathrm{g} / \mathrm{mL}$. After increasing the concentration to $25 \mu \mathrm{g} / \mathrm{mL}$ AgEONP induced a significant amount of strand breaks ((6710 \pm 750$)$ strand breaks per cell) while AgCitrate-NPs did not damage the DNA.

\section{Inflammatory Reaction in PBCEC}

Apart from DNA damage, inflammatory reactions have also been associated with RONS

Thereby, we analyzed the expression of the pro-inflammatory markers Il-8, COX-2 and MMP-2 by Western Blot analysis and zymography (Figure 8). After exposure of PBCEC to AgEO-NPs in a concentration of $12.5 \mu \mathrm{g} / \mathrm{mL}$ and $25 \mu \mathrm{g} / \mathrm{mL}$ Il-8 protein levels were 1.54 \pm 0.09 fold and $2.38 \pm 0.42$ fold increased compared to control levels. AgCitrate-NPs, on the other hand, did not cause a significant increase of the Il- 8 secretion. COX-2 was also significantly upregulated by AgEONPs in a concentration of $25 \mu \mathrm{g} / \mathrm{mL}(1.65 \pm 0.09)$ but not $12.5 \mu \mathrm{g} /$ $\mathrm{mL}(0.93 \pm 0.21)$. AgCitrate-NPs did not regulate COX-2 expression. Finally, MMP-2 secretion was $1.56 \pm 0.16$ fold increased (AgEO-NP, 25 $\mu \mathrm{g} / \mathrm{mL}$ ). After treatment of PBCEC with AgEO-NPs in a concentration of $12.5 \mu \mathrm{g} / \mathrm{mL}$ and with AgCitrate-NPs $(12.5 \mu \mathrm{g} / \mathrm{mL}$ and $25 \mu \mathrm{g} / \mathrm{mL})$ the MMP-2 secretion was not significantly increased.

\section{Discussion}

In recent years, consumers have been exposed to an increasing amount of Ag-NPs due to their widespread use in medical and cosmetic industry. Still, their influence on human health has not yet been examined adequately. Even though it was already shown that systemically introduced Ag-NPs are able to enter the brain and also reach the choroid plexus $[7,15,16]$, their effect on BBB and blood-CSF barrier function remains widely unknown. In vivo studies were able to show that Ag-NPs induced BBB dysfunction, astrocyte swelling and neuronal degradation in the brain of rats [17]. Even though the choroid plexus is typically less than $5 \%$ of the brain weight, it possesses a large surface area $\left(75 \mathrm{~cm}^{2}\right)$ due to apical microvilli and membrane invaginations on the basolateral side [18]. Additionally, in respect to its function in secretion of CSF and the delivery of substances to the cerebral compartment, the blood flow is much higher than in most brain regions [19]. This increases the chances of the choroid plexus to be exposed to xenobiotics, such as nanoparticles. From our point of view, the influence of Ag-NPs on the cells of the blood-brain and the blood-CSF barrier should be under special observation, as these are pivotal for the protection of the brain.

We thereby compared the effect of two Ag-NPs with different surface modifications (Ethylene oxide and Citrate) and surface charges (AgCitrate-NP are more negatively charged) on cells of the BBB and blood-CSF barrier in vitro. We analyzed the impact on cell viability, barrier integrity, RONS generation, DNA damage and secretion of proinflammatory markers in cells of the BBB and blood-CSF barrier. This investigation addresses both the cytotoxicity of Ag-NPs towards PBCEC and PCPEC and their influence on barrier properties. Cytotoxic effects of the silver-nanoparticles lead to an increased barrier permeability and
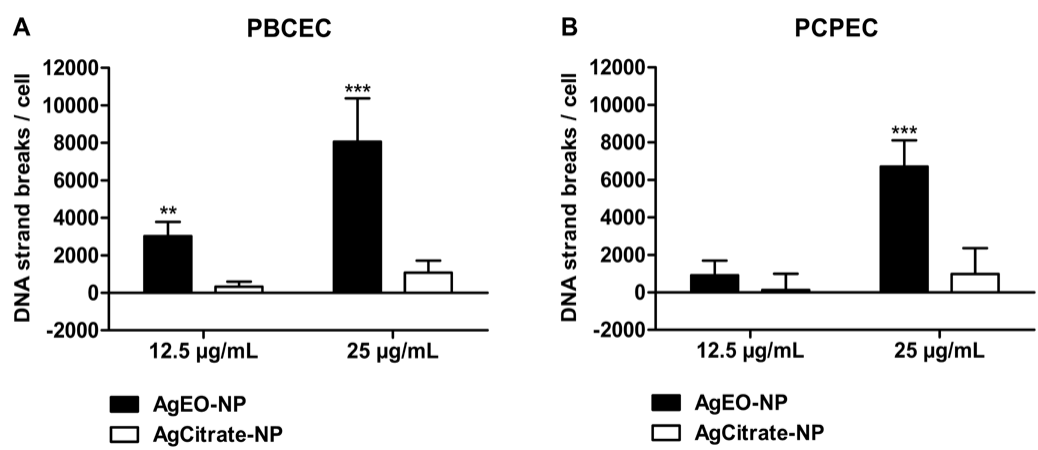

Figure 7: DNA strand breaks after treatment of PBCEC and PCPEC with AgEO- and AgCitrate-NPs for $24 \mathrm{~h}$.

A) DNA strand breaks in PBCEC. As positive control PBCEC were treated with $\mathrm{H}_{2} \mathrm{O}_{2}(100 \mu \mathrm{M}, 5$ min) which induced $7181 \pm 1557$ DNA strand breaks. B) DNA strand breaks in PCPEC. As positive control PCPEC were treated with $\mathrm{H}_{2} \mathrm{O}_{2}(100 \mu \mathrm{M}, 5$ min) which induced $8429 \pm 1169$ DNA strand breaks. The values are represented as mean \pm SEM. 

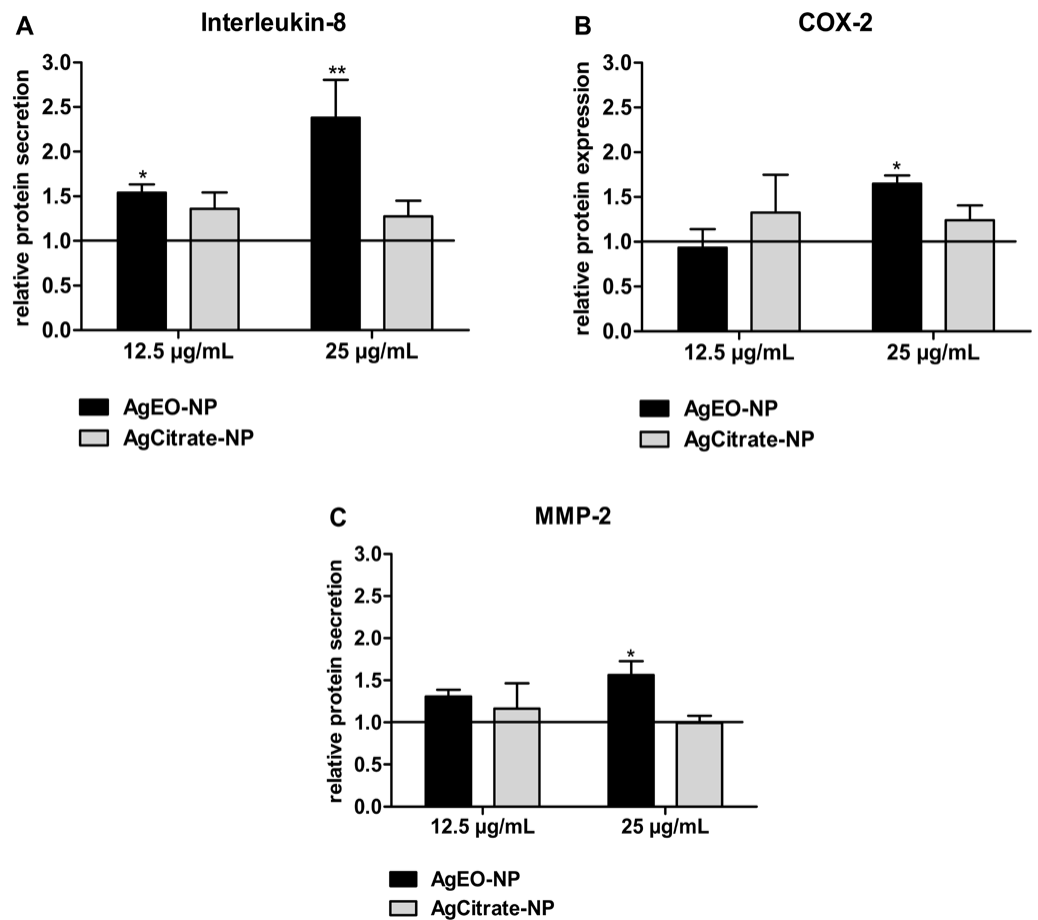

Figure 8: Protein expression of various inflammation markers after treatment of PBCEC with AgEO- and AgCitrate-NPs for $24 \mathrm{~h}$. Values are relative to the untreated control. Data are represented as means $\pm S E M, n \geq 3$.

A) relative protein secretion of Interleukin-8.

B) relative protein expression of COX-2.

C) relative protein secretion of MMP-2.

nanoparticle uptake into the brain. This may ultimately interfere with brain function.

Both AgEO- and AgCitrate-NPs induced a significant decrease of cell viability and a change of cell morphology at a concentration of $50 \mu \mathrm{g} / \mathrm{mL}$ in PBCEC, even though the effect was more pronounced for the AgEO- than for the AgCitrat-NPs. PCPEC, on the other hand, proved to be less susceptible to Ag-NPs and toxic effects were observed at much higher concentrations. This may be explained by the lesser cellular uptake in PCPEC as observed by TEM. In literature, only few in vitro studies concerning the effect of Ag-NPs on brain cells exist. So far, Trickler et al. [13] have conducted the only in vitro study in a primary BBB model. $40 \mathrm{~nm}$ Ag-NPs and $80 \mathrm{~nm} \mathrm{Ag-NPs} \mathrm{reduced} \mathrm{cell} \mathrm{viability} \mathrm{at}$ a concentration of $25 \mu \mathrm{g} / \mathrm{mL}(70 \%)$ and $50 \mu \mathrm{g} / \mathrm{mL}$ (60\%), respectively. Another recent study regarding the toxicity of Ag-NPs was conducted in a brain cell line (RBE4) by Grosse et al. [14]. The cytotoxicity of citrate-coated Ag-NPs in various sizes was examined. $50 \mathrm{~nm}$ Ag-NPs $(25 \mu \mathrm{g} / \mathrm{mL})$ induced a $46 \%$ reduction of neutral red uptake (lysosomal integrity) in the rat brain cell line RBE4 after $24 \mathrm{~h}$. In consideration of differences in the size and coating of the Ag-NPs as well as species, our results are in good agreement with the study of Trickler et al. and Grosse et al. [14]. Beside size Knaur et al. [20] considered the effect of charge on Ag-NPs toxicity. In contrast to our results, they found the more negatively charged NPs to be more cytotoxic and attributed this to their decreased formation of aggregates. However, this cannot be compared to the present study, as the Ag-NPs used here are stable in cell culture media and exhibit a similar amount of cluster formation within the cells, which became evident from the electron microscopy results.
The BBB and the blood-CSF barrier play a pivotal role in protecting the brain and maintaining its homeostasis. The uncontrolled influx of metabolites, ions and potentially toxic substances from the bloodstream could disturb the brains homeostasis [21,22] and damage the sensitive neurons, which are not able to regenerate. Ultimately this could interfere with important signal transduction pathways [21]. Still, the effects of Ag-NP on barrier integrity, permeability and tight junction formation have only been evaluated in a very limited number of studies. Trickler et al. [13] observed an increased permeability against fluorescein in rat brain microvascular endothelial cells after exposure to Ag-NPs, but effects on tight junction formation have not been evaluated. Martirosyan et al. [23] reported a decrease of TER and an increase of Luzifer Yellow permeability in Caco-2 cells upon exposure to Ag-NP. In addition, they also observed a change in distribution of the tight junction proteins occludin and ZO-1, which may have caused the barrier dysfunction. Within our study we have analyzed the TEER development, permeability against FITC-Dextrane as well as tight junction expression and distribution upon exposure of barrier-forming cells of CNS origin to Ag-NPs. Similarly to the studies of Trickler et al. [13] and Martyrosian et al. [23] we detected an increase of BBB permeability against FITC-Dextrane after exposure of PBCEC to Ag-NP which has also been confirmed by a decrease of the TER. Again, AgEO-NPs were found to induce a more severe permeability than AgCitrate-NPs. In contrast to PBCEC, AgEO- and AgCitrate-NPs did not impair barrier function in the epithelial cells of the choroid plexus. To understand the effect of Ag-NPs on barrier function on a molecular basis, we analyzed the expression and organization of tight junctions in barrier-forming cells of CNS origin. Upon exposure to AgEO-NPs we observed an increased occurrence of serrated and 
incomplete cell borders after staining occludin. However, a regulation of tight junction protein expression was not detected indicating that the observed impairment of barrier function in PBCEC is more likely due to changes in the formation of the tight junctions than to a decreased protein expression. Again, AgCitrate-NPs exhibited a much weaker effect on tight junction formation in PBCEC. The obtained results of tight junction expression and distribution support the TEER and permeability measurements and are in accordance with the studies of Trickler et al. [13] and Martirosyan et al. [23]. In addition, the immunofluorescence staining of occludin in the cells of the choroid plexus reveals undisturbed tight junctions, which supports the results of our TEER and permeability measurements. Hence, the results of our study reveal that Ag-NPs influence the permeability and the formation of tight junctions in PBCEC but not in PCPEC. To shed more light on the effects caused by AgEO- and AgCitrate-NPs we studied the uptake and cellular localization of the NPs by TEM. Both Ag-NPs exhibited a strong interaction with the cell membrane of PBCEC and were subsequently transported into the cells by endocytotic vesicles. Within the cell, the Ag-NPs formed aggregates in the cytoplasm and did not reach mitochondria or the nucleus. The formation of nanoparticle clusters within the cytoplasma of cells was already reported by different groups $[3,24,25]$ and various studies have suggested an endocytotic uptake mechanism for Ag-NP $[3,26]$. Whether the Ag-NPs reach the nucleus often depends on the NP size, as the diameter of the nuclear pores is about $20-50 \mathrm{~nm}$ depending on the cell type $[27,28]$. Thereby, the observed clustering may hinder the NPs from entering the nucleus. However, adverse effects can also be caused by Ag-NPs within the cytoplasma, for example through the release of $\mathrm{Ag}^{+}$ions [29,30]. A possible explanation for the lesser toxicity of AgCitrate-NPs compared to AgEO-NPs may also be a reduced release of $\mathrm{Ag}^{+}$ions. Dobias et al. have also reported that AgCitrate-NPs released fewer ions than AgPVP (polyvinylpyrrolidone)-NPs. PCPEC, on the other hand, showed no visible uptake of AgNPs. This may be due to the increased amount of microvilli present on the apical membrane, which may hinder the AgNPs from reaching the cell surface.

A number of studies suggest that the cytotoxic effects of Ag-NPs are due to the generation of reactive oxygen and nitrogen species (RONS) [31]. Reactive oxygen species include superoxide, hydrogen peroxide, singlet oxygen, ozone, hypohalous acids and organic peroxides while reactive nitrogen species consist of, for example, nitric oxide (NO.) and $\mathrm{NO}_{2}$. Aside from exogenous stimuli such as NPs, there are also many endogenous sources of RONS such as the mitochondrial respiratory chain, NADPH oxidases and cyclooxygenases [32]. For its protection, every cell also possesses a natural antioxidant capacity to restrict an overproduction of RONS. However, when said capacity is exceeded oxidative stress may occur which in turn may lead to damage of lipids, proteins and DNA as well as to the activation of pro-inflammatory signal cascades [33]. Hence, the potential of AgEO- and AgCitrate-NP to trigger oxidative stress and subsequent DNA damage was analyzed in PBCEC and PCPEC. The potential of Ag-NPs to trigger oxidative stress and DNA damage has already been shown in many studies $[5,20,29,34]$. However, this has not yet been elucidated in barrier-forming cells of the CNS. In the current study we showed that both AgEO- and AgCitrate-NPs were able to trigger the formation of RONS in PBCEC in a concentration-dependent manner. The amount of RONS was much higher after exposure to AgEO- than to AgCitrate-NPs, which again confirms the previous results from this study. The observed absence of Ag-NPs from the mitochondria of the cells implies that the increase in RONS may rather be due to the release of $\mathrm{Ag}^{+}$than to the $\mathrm{Ag}-\mathrm{NPs}$ themselves, which was found in other studies as well $[29,30]$ and has been termed the "Trojan Horse Theory" [30]. Also, the citrate-coating may reduce the release of $\mathrm{Ag}^{+}$from the Ag-NPs which might offer an explanation for the decreased potential of the AgCitate-NPs to generate RONS. In PCPEC, RONS was generated only after exposure to AgEONPs and to a much lesser extent than in PBCEC. This may be due to the strongly decreased uptake of Ag-NPs in PCPEC compared to PBCEC. We have also shown that DNA strand breaks occur in PBCEC only after treatment with AgEO-NPs but not AgCitrate-NPs. This is in accordance with the results of the RONS measurement and indicates the involvement of RONS in DNA damage. AgEO-NPs also induced strand breaks in PCPEC, but only at a concentration of $25 \mu \mathrm{g} / \mathrm{mL}$ and to a slightly lesser extent, which is in agreement with the results of the RONS measurement and the TEM pictures. In the study of Suliman et al. [34] a slight RONS generation was observed in A549 cells after exposure to Ag-NPs $(56 \mathrm{~nm}$ ) starting at a concentration of $25 \mu \mathrm{g} / \mathrm{mL}$. In addition, DNA damage was detected in the Comet-Assay and was already evident at subtoxic concentrations which did not even elicit RONS. Xiang et al. [29] evaluated the potential of BSA-coated AgNPs $(15 \mathrm{~nm})$ to cause genotoxicity in CHO-K1. While DNA adducts were already detected at small, non-toxic concentrations $(1 \mu \mathrm{g} / \mathrm{mL})$ the formation of 8-oxo-guanosin and micronuclei formation were only found at toxic concentrations that also elicited RONS. Several other studies also report DNA damage at both toxic and subtoxic concentrations. However, this is the first study to show that Ag-NPs induce DNA damage at the BBB and the blood-CSF barrier in vitro in a time- and concentration-dependent manner. The results within this study also demonstrate that damage, at the molecular level, is often found at subtoxic concentrations and that consequences might only arise in the long-term. Apart from DNA damage, RONS were also found to induce BBB permeability and breakdown [35-37]. Thereby, the observed barrier disruption may, at least partly, be due to RONS generation. In literature, it was also reported that RONS lead to either tight junction downregulation [38,39] or redistribution [40], probably depending on the kind of RONS elicited and the cells used. As we have observed a changed distribution of occludin in conjunction with a decrease of TEER, the results of this study are in agreement with literature. Another hint to the involvement of RONS in barrier breakdown is the observed concentration-dependency of the different effects. Small concentrations of Ag-NPs lead to a response in RONS but do not affect barrier integrity or cell viability. Greater concentrations however, which elicit a stronger amount of RONS start to affect barrier integrity and, only at high concentrations, cell viability is decreased.

The production of RONS is often associated with pro-inflammatory processes. Therefore we examined the protein expression of the pro-inflammatory markers Il-8, COX-2 and MMP-2. MMPs are endopeptidases which play a pivotal role in the remodeling of the extracellular matrix. Also, an enhanced activity of these enzymes has been found under neuroinflammatory conditions [41] and under the influence of RONS [42]. Under the influence of AgEO-NPs all inflammation markers were significantly upregulated, while AgCitrateNPs did not induce a heightened expression. This underlines the results of Trickler et al. [13] who also reported an enhanced secretion of the pro-inflammatory markers Prostaglandin $\mathrm{E}_{2}$, TNF- $\alpha$ and Il-1 $\beta$ in a primary BBB model. The most pronounced release of all markers was found for Ag25-NP $(50 \mu \mathrm{g} / \mathrm{mL})$ while $\mathrm{Ag} 40-\mathrm{NP}(50 \mu \mathrm{g} / \mathrm{mL})$ only led to a slight but not significant increase of Prostaglandin E and Il$1 \beta$. TNF- $\alpha$, on the other hand, was significantly upregulated. Again, the nature of the Ag-NPs used has a great impact on its influence on cells. In addition to the study of Trickler et al. [13] many other studies have also found an induction of pro-inflammatory markers by 
various Ag-NPs $[5,34,43,44]$. However, this is the first study to report the upregulation of MMP-2 under the influence of Ag-NPs, which is another hint to the involvement of RONS. In addition, MMPs were already shown to be an important factor to the destabilization of the $\mathrm{BBB}$ [37], and to be involved in the RONS-mediated break-down of the $\mathrm{BBB}$ in neurodegenerative and -inflammatory diseases [45-47].

\section{Conclusion}

Taken together, our results suggest a strong involvement of RONS in the observed toxicity of Ag-NPs. This is also supported by the concentration-dependency of our results. The first response to be activated in both PBCEC and PCPEC is the generation of RONS. As the amount of RONS rises with the concentration of Ag-NPs, an impairment of barrier function is found followed by DNA damage, and at least, reduction of cell viability. In addition, we have clearly shown that surface coating plays a pivotal role in governing the toxic potential of Ag-NPs. The more negatively charged AgCitrate-NPs exhibited a less pronounced effect on the BBB and the blood-CSF-barrier in vitro. This was evident throughout this study, including the parameters barrier impairment, RONS, DNA damage and regulation of inflammation markers. As we observed no difference in the uptake of AgEO- and AgCitrate-NPs into PBCEC via TEM, the lesser response of the PBCEC to these NPs could be due to a decreased release of $\mathrm{Ag}^{+}$from the particles surface. The results within this paper are a first evidence for the toxicity of Ag-NPs towards cells of brain origin. However, to verify whether the used concentrations are in a relevant range concerning living animals and to characterize the NPs influence on brain function, in vivo studies have to be conducted.

\section{Materials and Methods}

\section{Nanoparticle characterization}

AgEO- and AgCitrate-NPs were produced, characterized and provided by Bayer Technology Services. The primary particle size of the AgEO-NPs ranges between $2-85 \mathrm{~nm}$, the $d_{90}$ value is $28 \mathrm{~nm}$. The agglomeration size was determined by dynamic light scattering and was found to be $34 \mathrm{~nm}$. The isoelectrical point of AgEO-NPs was found at $\mathrm{pH}$ 2.5. The primary particle size of the AgCitrate-NPs ranges between 5-65 nm, the $d_{90}$ value was found to be $34 \mathrm{~nm}$. The agglomeration size was determined by dynamic light scattering and was found to be $37 \mathrm{~nm}$. The isoelectric point of AgCitrate-NPs was found at $<\mathrm{pH} 2$. It was found that both AgEO- and AgCitrate-NPs were stable in cell culture medium. The NP solutions were diluted from their respective stock solutions with ultrapure water and stirred for at least $24 \mathrm{~h}$, but not sonicated, prior to use in the experiments.

\section{Cell culture}

Primary porcine brain capillary endothelial cells (PBCEC) were isolated, cultivated and cryopreserved as described before [48]. On DIV 2, PBCEC were gently thawed and seeded in plating medium (Medium 199 Earle supplemented with $10 \%$ newborn calf serum (NCS), $0.7 \mathrm{~mm}$ L-glutamine, $100 \mu \mathrm{g} / \mathrm{ml}$ gentamycin, $100 \mathrm{units} / \mathrm{ml}$ penicillin, $100 \mu \mathrm{g} /$ $\mathrm{ml}$ streptomycin (all Biochrom)). From DIV 4 onwards PBCEC were cultured with serum-free medium (SFM, Dulbecco's modified Eagle's medium/Ham's F-10 (1:1) supplemented with $4.1 \mathrm{mM}$ L-glutamine, 100 $\mu \mathrm{g} / \mathrm{ml}$ gentamycin, $100 \mathrm{units} / \mathrm{ml}$ penicillin, $100 \mu \mathrm{g} / \mathrm{ml}$ streptomycin (all Biochrom). Depending on the experimental conditions the medium also contained $55 \mathrm{nM}$ hydrocortisone (HC) or $550 \mathrm{nM}$ HC to induce differentiation.

Primary porcine choroid plexus epithelial cells (PCPEC) were isolated and cultivated as described before [49]. After seeding of PCPEC the medium was changed every second day. On DIV 8 the medium was changed to serum-free medium (DMEM/Ham's F 12 (1:1) supplemented with $4 \mathrm{mM}$ L-glutamine, $100 \mathrm{units} / \mathrm{ml}$ penicillin, $100 \mu \mathrm{g} /$ $\mathrm{ml}$ streptomycin, and $5 \mu \mathrm{g} / \mathrm{ml}$ insulin) to allow full differentiation. The cells were further supplemented with serum-free medium on DIV 11 and the experiments were started on DIV 13.

\section{Neutral red uptake assay}

The cytotoxic effects of Ag-NPs on PBCEC and PCPEC were evaluated by employing the Neutral Red Uptake Assay. The assay is based on the ability of viable cells to incorporate and bind the supravital dye neutral red in the lysosomes [50]. Both PBCEC and PCPEC were cultured on 96-well culture plates. In case of PBCEC, the plates were coated with rat tail collagen. The treatment of PBCEC and PCPEC with Ag-NPs was started on DIV 6 and DIV13, respectively. After $24 \mathrm{~h}$ the medium was replaced by neutral red (3-amino-7-dimethylamino2-methylphenazinehydrochloride) containing medium (PBCEC: 0.2 $\mathrm{mg} / \mathrm{mL}$, PCPEC $0.06 \mathrm{mg} / \mathrm{mL})$. After dye loading $\left(37^{\circ} \mathrm{C}, 3 \mathrm{~h}\right)$, cells were washed with phosphate-buffered saline (PBS) containing $0.5 \%$ formaldehyde (Roth, Karlsruhe, Germany). The incorporated dye was solubilized in $100 \mu \mathrm{L}$ of acidified ethanol solution (50\% ethanol, $1 \%$ acetic acid in PBS), and finally the absorbance in each well was measured using a plate reader (Microplate TECAN reader MR700) at $540 \mathrm{~nm}$.

\section{Assessment of cell morphology}

PBCEC and PCPEC were cultured as described above. PBCEC and PCPEC were treated with Ag-NPs on DIV 7 and DIV 13, respectively. After $24 \mathrm{~h}$ the cell morphology was observed using a Leica DC300F microscope.

\section{Scanning electron microscopy}

After treatment with nanoparticles, the samples were pre-fixed with $2.5 \%$ glutaraldehyde in 0.1 molar sodium cacodylate buffer for at least $24 \mathrm{~h}$. Afterwards, the samples were meticulously rinsed with sodium cacodylate buffer. For scanning electron microscopy (SEM) investigations, post-fixation and pre-staining was realized by washing with $1 \%$ osmium tetroxide (Roth, Germany) in 0.1 molar sodium cacodylate buffer. Thereafter, the specimens were dehydrated in an ethanol series $(1 \times 30 \%, 1 \times 50 \%, 2 \times 70 \%, 1 \times 90 \% 2 \times 100 \%)$ and afterwards critical-point-dried. In order to increase the electrical conductivity the samples were coated with approximate $2 \mathrm{~nm} \mathrm{Pt} / \mathrm{C}$ (for details see [51]). Images were taken in the secondary electron (SE) and backscattered electron (BSE) mode. Here, an in-lens high-resolution scanning electron microscope (S5000 HITACHI, Japan) was utilized. All SE and BSE micrographs were recorded at an acceleration voltage of $25 \mathrm{kV}$ with a probe current of approximately $5 \mu \mathrm{A}$.

\section{Transmission electron microscopy}

For observations by transmission electron microscopy (TEM) the samples were pre-fixed with sodium cacodylate-buffered $2.5 \%$ glutaraldehyde and washed intensively with buffer. In contrary to the SEM preparation, post-fixation and pre-staining were realized by washing with $1 \%$ osmium tetroxide and $1.5 \%$ potassium ferrocyanide in 0.1 molar sodium cacodylate buffer. Subsequent to this preparation step, the specimens were again stained with $1 \%$ osmium tetroxid in 0.1 molar sodium cacodylate buffer and subsequently washed in the same buffer in two consecutive steps. As for the SEM preparation, samples were dehydrated in an ethanol series $(1 \times 30 \%, 1 \times 50 \%, 1 \times 70 \%, 1 \times 90 \%$ 
$2 \times 100 \%)$. Afterwards, the samples were embedded in Epon resin (Electron Microscopy Sciences) and sectioned after polymerisation of the resin (for details see [51]). Thin sections (thickness approximately $60 \mathrm{~nm}$ ) were post-stained with $2 \%$ uranyl acetate and Reynolds lead citrate stain and finally examined in a Philips CM10 (FEI, Netherlands) at $80 \mathrm{kV}$.

\section{Transcellular electrical resistance measurements and permeability measurements}

For transcellular electrical resistance (TER) measurements microporous polycarbonate membrane filters (Corning, Wiesbaden, Germany; $0.4 \mu \mathrm{m}$ pores; $1.13 \mathrm{~cm}^{2}$ growth area) were coated with rattail collagen. PBCEC were seeded at a density of $250.000 \mathrm{cells} / \mathrm{cm}^{2}$ and cultured as described above. On DIV 4 plating media was changed to SFM supplemented with $550 \mathrm{nM} \mathrm{HC}$. The experiments were performed on DIV 6. PCPEC were seeded on Matrigel ${ }^{\text {tst }}$-coated (Sigma-Aldrich) microporous polycarbonate membrane filters (Corning, Wiesbaden, Germany; $0.4 \mu \mathrm{m}$ pores; $1.13 \mathrm{~cm}^{2}$ growth area) in a density of $30 \mathrm{~cm}^{2} / \mathrm{g}$ wet weight of $\mathrm{CP}$ tissue and cultured as described above. The resistance and capacity of the PBCEC and PCPEC were monitored during $24 \mathrm{~h}$ with the CellZScope device (NanoAnalytics, Münster, Germany) after addition of Ag-NPs in their corresponding concentrations. For data analysis, the TEER values obtained were normalized to their corresponding starting values prior to NP addition. Only PBCEC with capacitance values between 0,45 and $0,6 \mu \mathrm{F} / \mathrm{cm}^{2}$, revealing a confluent cell monolayer were used. In case of PCPEC, only cells exhibiting capacity values of more than $3.3 \mu \mathrm{F} / \mathrm{cm}^{2}$ were employed in the experiments.

For the detection of macromolecular passage across the monolayer, a tracer solution containing fluorescein isothiocyanate labeled Dextran (FITC-Dextran) was prepared in medium. FITC-Dextran was added to the apical side of the Transwell filter. The concentration at the basolateral side was measured after $24 \mathrm{~h}$ using a Berthold Mithras LB 940 Luminometer (Berthold, Bad Wildbad, Germany), at emission/ excitation wavelengths of $492 / 535 \mathrm{~nm}$. During the experiment TER values of the respective filters were monitored as well.

\section{Immunostaining analysis}

For analysis of the tight junction protein occludin the PBCECs and PCPECs were cultivated on Transwell filters as described above. First, cells were fixed with $4 \%$ paraformaldehyde for $10 \mathrm{~min}$, permeabilized with $0.2 \%$ Triton X-100 for 10 min and blocked with 3\% BSA solution (bovine serum albumin). Cells were incubated overnight at $4^{\circ} \mathrm{C}$ with the primary antibody mouse anti-occludin $(1 \mu \mathrm{g} / \mathrm{ml}$, Zytomed, Berlin, Germany), then washed with PBS and blocked with 3\% BSA in PBS for 30 min. Afterwards the PBCEC were incubated with Alexa Fluor 546 goat anti-mouse antibody $(2 \mu \mathrm{g} / \mathrm{mL}$, Invitrogen, Paisley, UK) for $1 \mathrm{~h}$ at $37^{\circ} \mathrm{C}$. The sample filters were thoroughly washed, cut out from the inserts, and mounted in Aqua Poly/Mount (Polysciences, Washington, USA). After drying for at least $24 \mathrm{~h}$, the microscopy analysis was carried out.

\section{Detection of reactive oxygen and nitrogen species}

The PBCEC were seeded on 96-well plates coated with collagen $\mathrm{G}$ and cultured with $55 \mathrm{nM} \mathrm{HC}$ as described above. For detection of cellular RONS (DIV 6) the corresponding cells were pre-incubated with $\mathrm{H}_{2}$ DCF-DA (PBCEC: $10 \mathrm{~min}, 10 \mu \mathrm{M}$; PCPEC: $\left.10 \mathrm{~min}, 15 \mu \mathrm{M}\right)$. Then the cells were treated with Ag-NPs in various concentrations using 6 wells per condition. The fluorescence was measured immediately after addition of Ag-NPs and after $0.5 \mathrm{~h}, 1 \mathrm{~h}, 2 \mathrm{~h}, 4 \mathrm{~h}, 6 \mathrm{~h}$ and $24 \mathrm{~h}$ at an excitation wavelength of $485 \mathrm{~nm}$ and an emission wavelength of $520 \mathrm{~nm}$. For each condition fluorescence values from CDM without $\mathrm{H}_{2}$ DCF-DA were substracted. For Ag-NPs values from CDM + Ag-NPs were substracted. The corrected values were normalized to the values of the untreated control.

\section{Detection of DNA strand breaks}

DNA strand breaks were identified by alkaline unwinding as described previously $[52,53]$. Briefly, PBCEC were cultured to confluence on collagen $\mathrm{G}$ coated petri dishes (SFM $+55 \mathrm{nM}$ hydrocortisone) as described above. Ag-NPs were added at DIV 6 and the experiment was performed after an incubation time of $24 \mathrm{~h}$. As positive control, cells were incubated for $5 \mathrm{~min}$ with $100 \mu \mathrm{M} \mathrm{H}_{2} \mathrm{O}_{2}$. Thereafter the medium was removed, cells were washed with $\mathrm{PBS}$ and an alkaline solution $\left(0.03 \mathrm{M} \mathrm{NaOH}, 0.02 \mathrm{M} \mathrm{Na}_{2} \mathrm{HPO}_{4}\right.$ and $\left.0.9 \mathrm{M} \mathrm{NaCl}\right)$ was added. After neutralization and sonication, single- and double-stranded DNA was separated on $0.5 \mathrm{~mL}$ hydroxylapatite columns at $60^{\circ} \mathrm{C}$. Single- and double-stranded DNA was eluted with $1.5 \mathrm{~mL}$ of $0.15 \mathrm{M}$ and $0.35 \mathrm{M}$ potassium phosphate buffer, respectively. The DNA content of both fractions was determined by incubation with Hoechst 33258 dye in a final concentration of $7.5 \times 10^{-7} \mathrm{M}$ and measurement of the fluorescence with a microtiter fluorescence reader (SPECTRA Fluor, Tecan) at an excitation wavelength of $360 \mathrm{~nm}$ and an emission wavelength of 455 $\mathrm{nm}$. DNA strand breaks were quantified by calibration with X-rays as described previously [54].

\section{Western blotting}

The PBCEC were grown on culture flasks as described above (SFM $+55 \mathrm{nM} \mathrm{HC}$ ). The cells were treated with Ag-NPs on DIV 6 for 24 $\mathrm{h}$. Then cells were lysed and isolated as described before [37]. In case of Interleukin-8 PBCEC were grown on collagen $\mathrm{G}$ coated petri dishes $\left(10 \mathrm{~cm}^{2}\right)$ and treated with Ag-NPs for $24 \mathrm{~h}$, then the supernatant was collected and centrifuged. For detection of COX-2 the total protein amount was detected by use of bicinchonic assay, thereby ensuring that equal amounts of protein per condition were used. For detection of Il-8 equal volumes of the supernatant were mixed with the $4 \mathrm{x}$ sodium dodecylsulfate buffer $(0.4 \mathrm{M}$ Tris $/ \mathrm{HCl}, 8 \%(\mathrm{w} / \mathrm{v})$ sodium dodecyl sulfate, $4 \mathrm{mM}$ EDTA, $40 \%$ (v/v) glycerol, $2 \%$ mercaptoethanol, $\mathrm{pH}$ 6.8). Then the protein solutions were denatured for $5 \mathrm{~min}$ at $90^{\circ} \mathrm{C}$ and afterwards separated by sodium dodecylsulfate polyacrylamide gel electrophoresis. The separated proteins were transferred to a nitrocellulose membrane (HybondTM ECL, GE Healthcare, Freiburg, Germany). Membranes were blocked with $5 \%(\mathrm{w} / \mathrm{v})$ milk powder in tris-buffered saline buffer $(25 \mathrm{mM}$ Tris/ $\mathrm{HCl}, 150 \mathrm{mM} \mathrm{NaCl}, \mathrm{pH} 8.0$, $0.1 \%(\mathrm{v} / \mathrm{v})$ Tween $)$ and the proteins of interest were identified using the primary antibodies rabbit anti-COX $-2(0.5 \mu \mathrm{g} / \mathrm{mL}$, Abcam), mouse anti Il-8 $(0.5 \mathrm{mg} / \mathrm{ml}$ Thermo Fisher, Rockford, IL, USA) and mouse anti-GAPDH $(0.5 \mu \mathrm{g} / \mathrm{mL}$, Novus Biological, Littleton, CO, USA). As secondary antibodies anti-rabbit IgG horse radish peroxidase conjugate $(1 \mu \mathrm{g} / \mathrm{mL}$, Millipore, Termecula, CA, USA) or anti-mouse horse radish peroxidase conjugate $(0.8 \mu \mathrm{g} / \mathrm{mL}$, Sigma-Aldrich, Munich, Germany) were used. The detection was performed by employing the enhanced chemiluminescence kit (Amersham, Munich, Germany). The densitometric analysis was performed using the Argus XI program (Biostep $\mathrm{GmbH}$, Jansdorf, Germany), the quantification was carried out by employing the GenoSoft program (VWR International, Leuven, Belgium). In all experiments, proteins of unstimulated PBCEC (control) were isolated. The values of the stimulated PBCEC were normalized to the values GAPDH and expressed relative to the normalized values of the respective control cells. 
Citation: Cramer S, Tacke S, Bornhorst J, Klingauf J, Schwerdtle T, et al. (2014) The Influence of Silver Nanoparticles on the Blood-Brain and the Blood-Cerebrospinal Fluid Barrier in vitro. J Nanomed Nanotechnol 5: 225. doi: 10.4172/2157-7439.1000225

\section{Zymography}

The secretion of MMP-2 was analyzed by gelatin zymography. For this PBCEC were cultured on petri dishes as described above (SFM + 55 $\mathrm{nM} \mathrm{HC}$ ) and treated with Ag-NPs on DIV 6. After $24 \mathrm{~h}$ the supernatants were collected, centrifuged and mixed with equal volumes of sample buffer (20\% Glycin, 4\% SDS, 2 mM EDTA, 0.01\% bromphenol blue, $125 \mathrm{mM}$ Tris- $\mathrm{HCl}, \mathrm{pH}$ 6.8). Equal sample volumes were loaded on $10 \%$ SDS-PAGE which contained gelatin (Sigma-Aldrich, Munich, Germany). After electrophoresis, the gels were treated twice with $2.7 \%$ Trition-X-100 solution for $30 \mathrm{~min}$ and then incubated in developing buffer ( $50 \mathrm{mM}$ Tris, $200 \mathrm{mM} \mathrm{NaCl}, 5 \mathrm{mM} \mathrm{CaCl}, 0.02 \%$ Brij-35, pH $7.5)$ at $37^{\circ} \mathrm{C}$ for $22 \mathrm{~h}$. The following day, the gels were stained with the Colloidal Blue Staining Kit (Invitrogen, Darmstadt, Germany) according to the manufacture's manual. Densitometrical analysis of the gel was performed by ImageJ (version 1.45, NIH, Bethesda, MD, USA).

\section{Statistical analysis}

If not stated otherwise, results are expressed as mean \pm standard error of the mean (SEM). The statistical analysis was carried out by student's t-test comparing two groups. For multiple-group analysis, one-way analysis of variances (ANOVA) was used, followed by a Tukey test. $\mathrm{P}$ values $<0.05$ were considered significant with ${ }^{*}: \mathrm{p}<0.05 ;{ }^{* *}: \mathrm{p}<$ $0.01{ }^{* *}: \mathrm{p}<0.001$.

\section{Acknowledgement}

This project has been supported by BMBF-Verbundvorhaben NanoGEM Nanostrukturierte Materialien - Gesundheit, Exposition und Materialeigenschaften, Contract Nr. 03X0105M. The authors would also like to thank Bayer Technology Services for producing, characterizing and providing the silver nanoparticles. Furthermore, the authors would like to thank Ulrike Keller and Christiane Rasch for help during the SEM preparation and Ursula Malkus and Andrea Ricker for the support during the TEM preparation.

\section{References}

1. Ahamed M, Alsalhi MS, Siddiqui MK (2010) Silver nanoparticle applications and human health. Clin Chim Acta 411: 1841-1848.

2. Johnston HJ, Hutchison G, Christensen FM, Peters S, Hankin S, et al. (2010) A review of the in vivo and in vitro toxicity of silver and gold particulates: particle attributes and biological mechanisms responsible for the observed toxicity. Crit Rev Toxicol 40: 328-346

3. AshaRani PV, Low Kah Mun G, Hande MP, Valiyaveettil S (2009) Cytotoxicity and genotoxicity of silver nanoparticles in human cells. ACS Nano 3: 279-290.

4. Chairuangkitti $P$, Lawanprasert $S$, Roytrakul $S$, Aueviriyavit $S$, Phummiratch D, et al. (2013) Silver nanoparticles induce toxicity in A549 cells via ROSdependent and ROS-independent pathways. Toxicol In Vitro 27: 330-338.

5. Park MV, Neigh AM, Vermeulen JP, de la Fonteyne LJ, Verharen HW, et al (2011) The effect of particle size on the cytotoxicity, inflammation, developmental toxicity and genotoxicity of silver nanoparticles. Biomaterials 32: 9810-9817.

6. Haase A, Rott S, Mantion A, Graf P, Plendl J, et al. (2012) Effects of silver nanoparticles on primary mixed neural cell cultures: uptake, oxidative stress and acute calcium responses. Toxicol Sci 126: 457-468.

7. van der Zande M, Vandebriel RJ, Van Doren E, Kramer E, Herrera Rivera Z, et al. (2012) Distribution, elimination, and toxicity of silver nanoparticles and silver ions in rats after 28-day oral exposure. ACS Nano 6: 7427-7442.

8. Genter MB, Newman NC, Shertzer HG, Ali SF, Bolon B (2012) Distribution and systemic effects of intranasally administered $25 \mathrm{~nm}$ silver nanoparticles in adult mice. Toxicol Pathol 40: 1004-1013.

9. Tang J, Xiong L, Zhou G, Wang S, Wang J, et al. (2010) Silver nanoparticles crossing through and distribution in the blood-brain barrier in vitro. J Nanosci Nanotechnol 10: 6313-6317.

10. Abbott NJ, Patabendige AA, Dolman DE, Yusof SR, Begley DJ (2010) Structure and function of the blood-brain barrier. Neurobiol Dis 37: 13-25.
11. Strazielle N, Ghersi-Egea JF (2000) Choroid plexus in the central nervous system: biology and physiopathology. J Neuropathol Exp Neurol 59: 561-574.

12. Barone FC, Feuerstein GZ (1999) Inflammatory mediators and stroke: new opportunities for novel therapeutics. J Cereb Blood Flow Metab 19: 819-834.

13. Trickler WJ, Lantz SM, Murdock RC, Schrand AM, Robinson BL, et al. (2010) Silver nanoparticle induced blood-brain barrier inflammation and increased permeability in primary rat brain microvessel endothelial cells. Toxicol Sci 118 160-170.

14. Grosse S, Evje L, Syversen T (2013) Silver nanoparticle-induced cytotoxicity in rat brain endothelial cell culture. Toxicol In Vitro 27: 305-313.

15. Lee JH, Kim YS, Song KS, Ryu HR, Sung JH, et al. (2013) Biopersistence of silver nanoparticles in tissues from Sprague-Dawley rats. Part Fibre Toxicol 10: 36 .

16. Park EJ, Bae E, Yi J, Kim Y, Choi K, et al. (2010) Repeated-dose toxicity and inflammatory responses in mice by oral administration of silver nanoparticles. Environ Toxicol Pharmacol 30: 162-168.

17. Sharma HS, Ali SF, Hussain SM, Schlager JJ, Sharma A (2009) Influence of engineered nanoparticles from metals on the blood-brain barrier permeability, cerebral blood flow, brain edema and neurotoxicity. An experimental study in the rat and mice using biochemical and morphological approaches. J Nanosci Nanotechnol 9: 5055-5072.

18. Keep RF, Jones HC (1990) A morphometric study on the development of the lateral ventricle choroid plexus, choroid plexus capillaries and ventricular ependyma in the rat. Brain Res Dev Brain Res 56: 47-53.

19. Davson H, Segal MB (1996) Physiology of the CSF and blood-brain barriers CRC Press, Boca Raton, FI

20. Kaur J, Tikoo K (2013) Evaluating cell specific cytotoxicity of differentially charged silver nanoparticles. Food Chem Toxicol 51: 1-14.

21. Hawkins BT, Davis TP (2005) The blood-brain barrier/neurovascular unit in health and disease. Pharmacol Rev 57: 173-185.

22. Lim DA, Huang YC, Alvarez-Buylla A (2007) The adult neural stem cell niche: lessons for future neural cell replacement strategies. Neurosurg Clin N Am 18 81-92, ix.

23. Martirosyan A, Bazes A, Schneider YJ (2014) In vitro toxicity assessment of silver nanoparticles in the presence of phenolic compounds--preventive agents against the harmful effect? Nanotoxicology 8: 573-582.

24. Kim TH, Kim M, Park HS, Shin US, Gong MS, et al. (2012) Size-dependent cellular toxicity of silver nanoparticles. J Biomed Mater Res A 100: 1033-1043.

25. Lapotko DO, Lukianova-Hleb EY, Oraevsky AA (2007) Clusterization of nanoparticles during their interaction with living cells. Nanomedicine (Lond) 2 241-253.

26. Drescher D, Guttmann P, Büchner T, Werner S, Laube G, et al. (2013) Specific biomolecule corona is associated with ring-shaped organization of silver nanoparticles in cells. Nanoscale 5: 9193-9198.

27. Fahrenkrog B, Aebi U (2003) The nuclear pore complex: nucleocytoplasmic transport and beyond. Nat Rev Mol Cell Biol 4: 757-766.

28. Wente SR (2000) Gatekeepers of the nucleus. Science 288: 1374-1377.

29. Jiang X, Foldbjerg R, Miclaus T, Wang L, Singh R, et al. (2013) Multi-platform genotoxicity analysis of silver nanoparticles in the model cell line CHO-K1. Toxicol Lett 222: 55-63.

30. Park EJ, Yi J, Kim Y, Choi K, Park K (2010) Silver nanoparticles induce cytotoxicity by a Trojan-horse type mechanism. Toxicol In Vitro 24: 872-878.

31. Rahman MF, Wang J, Patterson TA, Saini UT, Robinson BL, et al. (2009) Expression of genes related to oxidative stress in the mouse brain after exposure to silver-25 nanoparticles. Toxicol Lett 187: 15-21.

32. Nathan C, Cunningham-Bussel A (2013) Beyond oxidative stress: an immunologist's guide to reactive oxygen species. Nat Rev Immunol 13: 349361.

33. Nel A, Xia T, Mädler L, Li N (2006) Toxic potential of materials at the nanolevel. Science 311: 622-627.

34. Suliman YAO, Ali D, Alarifi S, Harrath AH, Mansour L, et al. (2013) Evaluation of cytotoxic, oxidative stress, proinflammatory and genotoxic effect of silver nanoparticles in human lung epithelial cells. Environ Toxicol. 
Citation: Cramer S, Tacke S, Bornhorst J, Klingauf J, Schwerdtle T, et al. (2014) The Influence of Silver Nanoparticles on the Blood-Brain and the Blood-Cerebrospinal Fluid Barrier in vitro. J Nanomed Nanotechnol 5: 225. doi: 10.4172/2157-7439.1000225

35. Fischer S, Wiesnet M, Renz D, Schaper W (2005) H2O2 induces paracellular permeability of porcine brain-derived microvascular endothelial cells by activation of the p44/42 MAP kinase pathway. Eur J Cell Biol 84: 687-697.

36. Witt KA, Mark KS, Sandoval KE, Davis TP (2008) Reoxygenation stress on blood-brain barrier paracellular permeability and edema in the rat. Microvasc Res 75: 91-96.

37. Lischper M, Beuck S, Thanabalasundaram G, Pieper C, Galla HJ (2010) Metalloproteinase mediated occludin cleavage in the cerebral microcapillary endothelium under pathological conditions. Brain Res 1326: 114-127.

38. Krizbai IA, Bauer H, Bresgen N, EckI PM, Farkas A, et al. (2005) Effect of oxidative stress on the junctional proteins of cultured cerebral endothelial cells. Cell Mol Neurobiol 25: 129-139.

39. Schreibelt G, Kooij G, Reijerkerk A, van Doorn R, Gringhuis SI, et al. (2007) Reactive oxygen species alter brain endothelial tight junction dynamics via RhoA, PI3 kinase, and PKB signaling. FASEB J 21: 3666-3676

40. Lee HS, Namkoong K, Kim DH, Kim KJ, Cheong YH, et al. (2004) Hydrogen peroxide-induced alterations of tight junction proteins in bovine brain microvascular endothelial cells. Microvasc Res 68: 231-238.

41. Yong VW, Power C, Forsyth P, Edwards DR (2001) Metalloproteinases in biology and pathology of the nervous system. Nat Rev Neurosci 2: 502-511.

42. Haorah J, Ramirez SH, Schall K, Smith D, Pandya R, et al. (2007) Oxidative stress activates protein tyrosine kinase and matrix metalloproteinases leading to blood-brain barrier dysfunction. J Neurochem 101: 566-576.

43. Martínez-Gutierrez F, Thi EP, Silverman JM, de Oliveira CC, Svensson SL, et al. (2012) Antibacterial activity, inflammatory response, coagulation and cytotoxicity effects of silver nanoparticles. Nanomedicine 8: 328-336.

44. Nishanth RP, Jyotsna RG, Schlager JJ, Hussain SM, Reddanna P (2011) Inflammatory responses of RAW 264.7 macrophages upon exposure to nanoparticles: role of ROS-NFÎ'B signaling pathway. Nanotoxicology 5: 502

45. Rosell A, Ortega-Aznar A, Alvarez-Sabín J, Fernández-Cadenas I, Ribó M et al. (2006) Increased brain expression of matrix metalloproteinase-9 after ischemic and hemorrhagic human stroke. Stroke 37: 1399-1406.
46. van Horssen J, Vos CM, Admiraal L, van Haastert ES, Montagne L, et al. (2006) Matrix metalloproteinase-19 is highly expressed in active multiple sclerosis lesions. Neuropathol Appl Neurobiol 32: 585-593.

47. Ghorpade A, Persidskaia R, Suryadevara R, Che M, Liu XJ, et al. (2001) Mononuclear phagocyte differentiation, activation, and viral infection regulate matrix metalloproteinase expression: implications for human immunodeficiency virus type 1-associated dementia. J Virol 75: 6572-6583.

48. Franke H, Galla HJ, Beuckmann CT (1999) An improved low-permeability in vitro-model of the blood-brain barrier: transport studies on retinoids, sucrose haloperidol, caffeine and mannitol. Brain Res 818: 65-71.

49. Bornhorst J, Wehe CA, Hüwel S, Karst U, Galla HJ, et al. (2012) Impact of manganese on and transfer across blood-brain and blood-cerebrospinal fluid barrier in vitro. J Biol Chem 287: 17140-17151.

50. Repetto G, del Peso A, Zurita JL (2008) Neutral red uptake assay for the estimation of cell viability/cytotoxicity. Nat Protoc 3: 1125-1131.

51. Bozzola JJ, Russel LD (1992) Electron Microscopy, Principles and Techniques for Biologists. Jones and Bartlett Publishers, Sudbury, Massachusetts

52. Schwerdtle T, Hamann I, Jahnke G, Walter I, Richter C, et al. (2007) Impact of copper on the induction and repair of oxidative DNA damage, poly(ADP-ribosyl) ation and PARP-1 activity. Mol Nutr Food Res 51: 201-210.

53. Walter I, Schwerdtle T, Thuy C, Parsons JL, Dianov GL, et al. (2007) Impact of arsenite and its methylated metabolites on PARP-1 activity, PARP-1 gene expression and poly(ADP-ribosyl)ation in cultured human cells. DNA Repair (Amst) 6: 61-70.

54. Hartwig A, Groblinghoff UD, Beyersmann D, Natarajan AT, Filon R, et al. (1997) Interaction of arsenic(III) with nucleotide excision repair in UV-irradiated human fibroblasts. Carcinogenesis 18: 399-405.

55. Lischper M Beuck S, Thanabalasundaram G, Pieper C, Galla HJ (2010) Metalloproteinase mediated occludin cleavage in the cerebral microcapillary endothelium under pathological conditions. See comment in PubMed Commons below Brain Res 1326: 114-127. 